OPEN ACCESS

Edited by:

Simone Libralato,

Istituto Nazionale di Oceanografia e di

Geofisica Sperimentale, Italy

Reviewed by:

Alex Souza Lira,

Federal University of the Parnaiba

Delta, Brazil

Moslem Daliri,

University of Hormozgan, Iran

${ }^{*}$ Correspondence:

Janayna Galvão Araújo

janaynagalvao@yahoo.com.br

tORCID:

Janayna Galvão Araújo orcid.org/0000-0001-7060-5310

Adauto dos Santos Mello Filho orcid.org/0000-0003-0279-1486

Ualerson Iran Peixoto

orcid.org/0000-0001-7078-3424

Bianca Bentes

orcid.org/0000-0002-4089-7970

Marcos Antonio Souza dos Santos

orcid.org/0000-0003-1028-1515

Jynessa Dutka-Gianelli orcid.org/0000-0001-5982-1506

Victoria Isaac

orcid.org/0000-0002-7652-2708

Specialty section:

This article was submitted to Marine Fisheries, Aquaculture

and Living Resources,

a section of the journal

Frontiers in Marine Science

Received: 25 October 2021

Accepted: 20 January 2022

Published: 08 March 2022

Citation:

Araújo JG, Mello Filho AdS, Peixoto UI, Bentes B, Santos MASd,

Dutka-Gianelli J and Isaac V (2022)

Multidimensional Evaluation of Brown

Shrimp Trawling Fisheries on

the Amazon Continental Shelf.

Front. Mar. Sci. 9:801758.

doi: 10.3389/fmars.2022.801758

\section{Multidimensional Evaluation of Brown Shrimp Trawling Fisheries on the Amazon Continental Shelf}

\author{
Janayna Galvão Araújo ${ }^{1,2 * t}$, Adauto dos Santos Mello Filho1,2t, Ualerson Iran Peixoto ${ }^{3,4 t}$, \\ Bianca Bentes ${ }^{1,2 t}$, Marcos Antonio Souza dos Santos ${ }^{5 t}$, Jynessa Dutka-Gianelli6t and \\ Victoria Isaac ${ }^{1,2 t}$ \\ 1 Programa de Pós-Graduação em Ecologia Aquática e Pesca (PPGEAP), Núcleo de Ecologia Aquática e Pesca da \\ Amazônia (NEAP), Universidade Federal do Pará (UFPA), Belém, Brazil, ${ }^{2}$ Laboratório de Biologia Pesqueira e Manejo dos \\ Recursos Aquáticos, Grupo de Ecologia e Manejo da Pescana Amazônia (GEMPA), Universidade Federal do Pará (UFPA), \\ Belém, Brazil, ${ }^{3}$ Institute of Marine Research - IMAR, University of the Azores, Horta, Portugal, ${ }^{4}$ Okeanos R\&D Centre, \\ University of the Azores, Horta, Portugal, ${ }^{5}$ Programa de Pós-Graduação em Agronomia, Universidade Federal Rural da \\ Amazônia (UFRA), Belém, Brazil, ${ }^{6}$ Gloucester Marine Station, University of Massachusetts Amherst, Gloucester, MA, \\ United States
}

Brown shrimp (Penaeus subtilis) trawling in the northern coastal waters of Brazil is an industrial fishing activity with a share in the international market and an important resource in the fishery market. Due to the scarcity of updated information on this practice and owing to its complexity, it is difficult to have a measurement of all dimensions of the development of this fishery, whether they are ecological, economic, or socialinstitutional. The present paper uses an assessment tool focused on data-poor fishery systems, the Fishery Performance Indicators (FPIs), to assess the multidimensional conditions of this fishery. The indicators were assessed between 2019 and 2020, and the metrics were based on public official data, scientific publications, in loco consultations with production agents, and databases of research projects. Results showed that the critical points of this activity are primarily related to the ecological indicator (1.75), which obtained a lower score compared to other fisheries assessed using the same methodology. This is due to its low selectivity, which results in high bycatch volumes and discards. The limited participation of productive chain actors also restrains the efficacy of management measures, which hampers successful resource management. This issue maximizes other setbacks throughout the productive chain, such as economic and social factors.

Keywords: by-catch, shrimp trawling, brown-shrimp, fisheries socio-economic, production chain Brazil

\section{INTRODUCTION}

The industrial modality of marine trawling has been increasing in several countries over time, standing out as an important and lucrative commercial activity (Pauly and Zeller, 2016). Among the resources exploited through this activity, crustaceans are one of the major catches, contributing to $15 \%$ of the entire economic value transacted throughout the world (Gillett, 2008; FAO, 2018, 2020). Crustacean catch ensures good profitability and excellent market value, being an important 
commodity for the producing countries (FAO, 2018). However, the growing demand to increase the fishery production in developing countries may threat the conservation of resources, as it can lead to over-exploitation of the species captured and to economic failure of the actors involved (Mansfield, 2011).

\section{Brown-Shrimp Fishery on the Northern Coast of Brazil}

Crustacean catch plays a key role in the national fishing economy in Brazil, making it a socially and economically significant activity (Isaac et al., 1992; Maia et al., 2016). In the Brazilian coast, shrimps commercially exploited belong to the Penaeidae family, namely: Penaeus paulensis (Perez Farfante, 1967; Perez Farfante and Kensley, 1997), Penaeus brasiliensis (Latreille, 1817), Penaeus subtilis (Perez Farfante, 1967; Perez Farfante and Kensley, 1997), and Xiphopenaeus kroyeri (Heller, 1862) (Worms, 2019), Ministério da Pesca e Aquicultura [MPA] (2011). The southern brown-shrimp - P. subtilis - is the most important species for the industrial trawling fleet that operates on the Amazon Continental Shelf (ACS), in northern Brazil (Martins et al., 2015).

Similar to other penaeids, the brown-shrimp has a complex life cycle in which juveniles inhabit estuaries of the coastal region while sub-adults migrate to oceans, where spawning takes place. These animals prefer muddy-sandy substrates, down to 190 meters depth, temperatures up to $27.5^{\circ} \mathrm{C}$, and the ability to resist large salinity changes throughout their life cycle (Pérez-Farfante, 1969; Holthuis, 1980; Kaschner et al., 2019).

The industrial brown-shrimp fishery on the Amazon Continental Shelf is annually performed by approximately 101 trawlers, primarily steel vessels, with a mean length of $20 \mathrm{~m}$, engine power varying from 235 to $470 \mathrm{Hp}$, onboard icing system, and average holding capacity of 20 tons per fishing trip. Vessels also have an onboard navigation system, echo sounder, and radio for communication (Frédou et al., 2009; Paiva et al., 2009; Aragão et al., 2015a; Bentes et al., 2017).

The average crew size is of five workers with predefined roles (master, cook, pilot, haulage engineman, fisher) and are typically salaried, receiving a fixed income and a financial increment, derived from the commission, according to their role in the vessel and to the amount of shrimps captured; the master is the highest pay and the fisher is the lowest pay.

Each trawler usually undertakes four trips over the year, with a average duration of 45 days, between February and November. Fishing grounds and capture time follow the migration pattern of shrimps toward the northeast, along the ACS (Martins et al., 2015; Peixoto et al., 2021).

The industrial fleet captures shrimps using double trawl nets with accessories (tangons) for hoisting the nets after each trawl (Aragão et al., 2001, 2015a,b). Yield is higher in the first half of the year, with $P$. subtilis being the predominant species in the catch. Other species that also occurring are P. brasiliensis and X. kroyeri, and a high diversity of fishes and other aquatic organisms that comprise the by-catch fauna (Cintra et al., 2004; Frédou et al., 2009; Aragão et al., 2015b; Marceniuk et al., 2019).

Most shrimp production captured at open sea is primarily intended for the processing industry and traded in the export market. The other part of the production is distributed in fairs, markets, restaurants, among other local or regional markets (Araújo, 2021; COMEX STAT, 2021).

The industrial exploitation of the brown-shrimp stock in the Amazon coast is considered one of the least sustainable practices among the fisheries conducted in this region (Isaac et al., 2009), especially due to the impact of trawling on by-catch fauna, which is captured incidentally and is mostly discarded (Hall et al., 2000; Allen et al., 2017; Bomfim et al., 2019).

Annually, an average of 3,800 tons of shrimp are caught in this activity, which represents an annual income of more than 41 million U\$ dollars. However, it is evident that the shrimp catch in this region has been decreasing over time, and the reasons are still unclear. It is due to the fact that stock assessment have never acknowledged this species as overexploited, and would theoretically still support an increased effort (Isaac et al., 1992; Aragão et al., 2015a; Araújo, 2021; Peixoto et al., 2021). However, the number of trawlers working with this type of activity has decreased for approximately 70 boats (Aragão et al., 2015a) and economic or institutional reasons are still to be further, but literature on this topic is scarce.

There are a few current fishery regulation measures designed to ensure higher sustainability in this activity. These measures are mostly based on the target species and consist primarily of (i) limiting the number of vessels authorized to conduct this fishery, which has been set at 101 trawlers (Brasil, 2017); (ii) banning trawling less than 10 nautical miles off the coast to prevent the capture of juveniles of several fish species (Brasil, 1987); (iii) defining the annual closure period, between December 15 and February 15 (Brasil, 2018), to protect spawning and recruitment; and (iv) regulating net-bag mesh size at $22 \mathrm{~mm}$ between opposed notches (Dias-Neto, 2011) to prevent small-sized species from entering the nets.

\section{Multidimensional Indicators for Fishery Diagnosis}

The fishery is a complex system, which requires a transdisciplinary and integrated approach. Over the last decades, as the concept of ecosystem-based management (EBMF) has emerged, the importance of a holistic assessment of the impacts caused by fishery has become clear, which not only includes the activity's ecological dimension but also the different economic and social dimensions (Ye, 1998; Willems, 2016; McConnaughey et al., 2019). The integrated analysis of social-economic and environmental systems has helped to obtain a more adequate management of the activity and can ensure higher sustainability in management rules (Rindorf et al., 2016; Chu et al., 2017). The lack of a transdisciplinary and ecosystem-based approach might be one of the causes for failures in more classic management measures and for the lack of long-term sustainability and governance in fisheries (Garcia et al., 2003).

Some methodologies have been developed over the past years to ensure better integration of environmental and socialeconomic factors in the analyses of fisheries (Bentes et al., 2012; Russo et al., 2017). Fisheries Performance Indicators (FPIs) have been devised to evaluate biological and non-biological 
characteristics, applying a holistic and multidimensional view to fishery systems. This is a quick and low-cost tool, designated "triple bottom line," which evaluates the status of fishery management systems using an array of metrics and indicators grouped in three sustainability dimensions: ecology, economics, and community (Anderson et al., 2015; Chu et al., 2017; Eggert et al., 2021).

Fishery Performance Indicator tools allow evaluating the stock status, environmental conditions of the fishery area, the performance of catch and post-harvest sectors, as well as market and resource management aspects (Anderson et al., 2015). This methodology can be applied to data-poor fishery systems, which are common in developing countries. Moreover, these indicators have already been applied to 149 fisheries worldwide (Eggert et al., 2021), which allows performing comparisons and list reference points, identifying weaknesses and strengths in each fishery, thus subsidizing decisions regarding problemsolving measures.

The absence of integrated information, particularly the lack of an assessment of the impacts on target and non-target species and on the degradation of the environments where catches are found, as well as the absence of an economic and political diagnosis of fishery production systems of economic importance, encumbers the determination of how effective the management systems are, and which interventions are required in the many stages of this activity, from harvest to the consuming market.

The present study aims to use the FPI tools for industrial brown-shrimp fisheries on the northern coast of Brazil. This fishery has been chosen based on its social-economic relevance to this region, as it generates employment and income, as well as significant revenue for the country. Fishery Performance Indicators are used as an attempt to tackle the lack of information on this activity through a holistic assessment, considering its environmental, economic, and community aspects, thus providing an opportunity to compare it with other fishery systems around the world and providing a broad view of the current fishery status, helping to design and provide recommendations for management measures.

\section{METHODOLOGY}

\section{Study Area}

The study area comprises the Amazon continental shelf, the northern region of Brazil, where the industrial trawling fleet of the brown-shrimp ( $P$. subtilis) operates. The fishery area extends over the Brazilian continental shelf, from the marine projection of the mouth of the Oiapoque River (on the border between the French Guiana and Brazil) to the mouth of the Parnaíba River (on the border between Piauí and Maranhão states, Brazil), with higher fishery intensity off the states of Amapá and Pará (Figure 1; Aragão et al., 2015a). Mean depths where fisheries were carried out varied from $40 \mathrm{~m}$ to over $100 \mathrm{~m}$, with a predominance of muddy, sandy and gravelly substrates (Aragão et al., 2015a; Isaac and Ferrari, 2017). This area is part of the North Brazil Large Marine Ecosystem (NBLME) and receives an important freshwater discharge derived from the Amazon and Tocantins Rivers, creating a highly dynamic and productive environment (Barthem and Schwassmann, 1994; Nittrouer and DeMaster, 1996).

\section{Fishery Performance Indicator Method}

Data were collected between 2019 and 2020 applying the Fisheries Performance Indicators (FPI) tool described by Anderson et al. (2015), which assessed fishery through 122 metrics that fit into dimensions or topics of interest, in order to characterize the fishery production system. The dimensions are classified into two main large categories, called "input" and "output."

The indicators of the output group are separated into three large groups, called "triple bottom line" (ecologic, economics, community), established in 14 dimensions containing 68 metrics. They reflect the activity's performance throughout the production process. The Input group is classified into five components, which contain 15 dimensions, with 54 metrics. These metrics represent the existing conditions (whether environmental or not) required to lead to a good performance of the activity (Figure 2). All metrics related to inputs and outputs are described in Supplementary Tables 1, 2, respectively.

Scores were assigned to assess the metrics (whether they are output or input), and they varied from 1 (worst performance) to 5 (best performance) based on pre-established quantitative and qualitative criteria (Anderson et al., 2016). Mean scores of the set of metrics determine the value of each dimension, and average dimensions determine the value of the component or indicator. This procedure obtains a more robust assessment, even when there are few data available in the details. In addition, the metrics are analyzed according to the reliability level of the information source, ranging from A (accurate information) to $\mathrm{C}$ (inaccurate information). Therefore, it is possible to weigh the degree of certainty of the results. According to the 122 metrics analyzed, the accuracy of the metrics according to the quality of information utilized was $17 \%$ type A, $68 \%$ B, and $15 \%$ type C information.

The data were inserted into Excel spreadsheets previously programmed to estimate averages and to design radar graphs that summarize the results obtained for shrimp fishery on the ACS. Dimension values were compared with the average scores found in 97 fisheries in developing countries and with the scores of 10 fisheries with the best performance according to the FPI method (Iceland Nephrops lobster, Icelandic cod, Australia Western zone abalone, US-Alaska pollock, Japan wagu lobster, Australia Southern zone rock lobster, Japan Ofunato set-net salmon, Australia Spencer Gulf prawn, Norway's purse seine, and Japan Toyama Bay set-net). These reference scores were obtained thanks to the collaboration with the research group that developed this method at the Institute for Sustainable Food Systems at the University of Florida and from available literature (Anderson et al., 2015; Asche et al., 2018).

\section{RESULTS AND DISCUSSION}

\section{Input Indicators Macro Factors}

The Macro factors component had an intermediate score (score: 3.2). Rains were the climatic factor that directly affects catches; however, it is considered a positive factor as it causes 


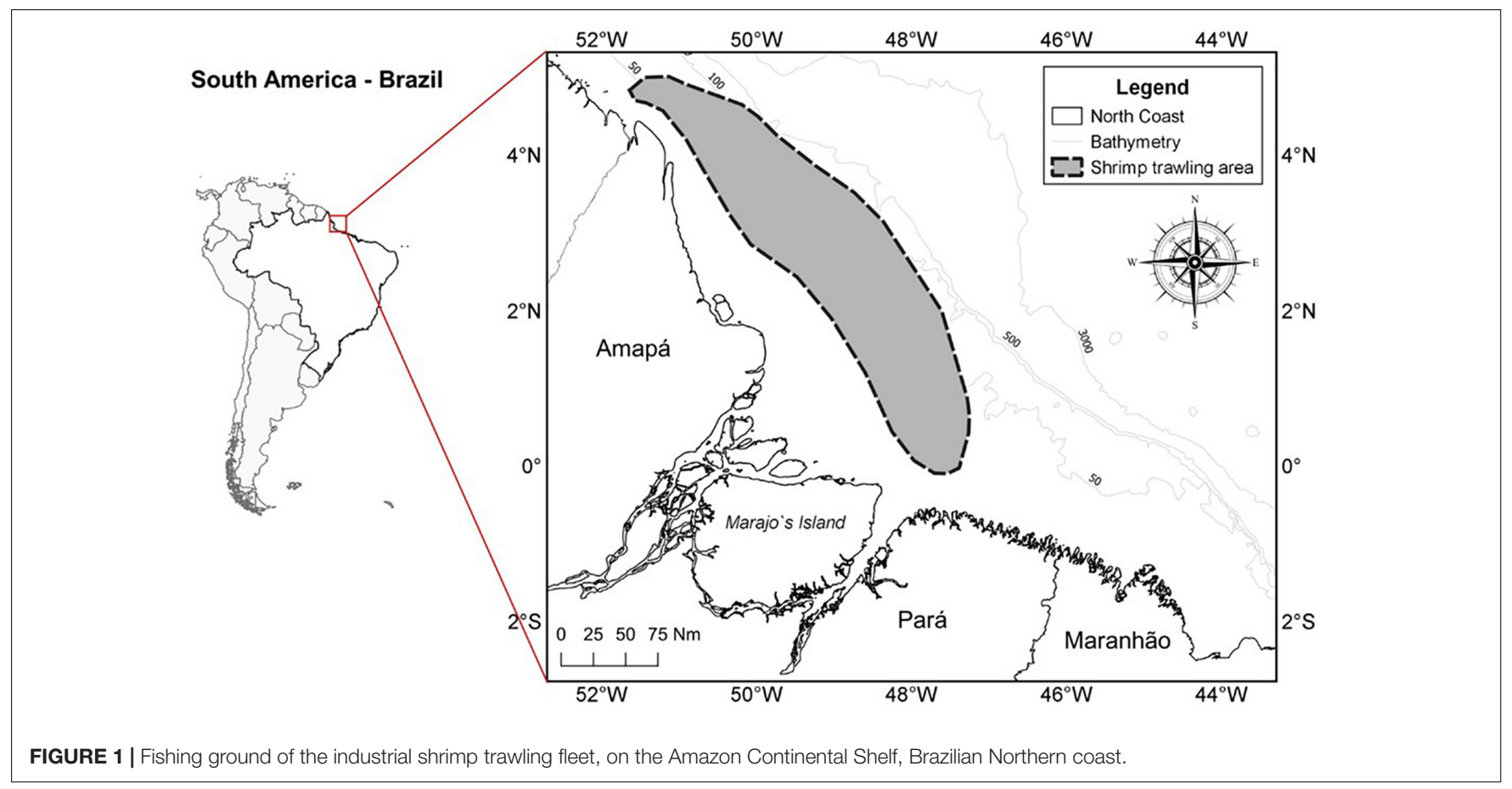

freshwater discharge from the Amazon River (Barthem and Schwassmann, 1994), thus increasing environment productivity, and consequently, shrimp productivity, particularly in areas off the coast (Aragão et al., 2015b). The low interference of natural disasters, such as cyclones or typhoons, in the Amazon region, increased the score of this dimension.

In spite of that, the metric Environmental Performance Index (EPI) was assigned a low score. According to the Yale group $^{1}$, which assesses sustainability levels worldwide according to environmental criteria, such as air quality, climate changes, waste management, etc., Brazil does not have suitable policies for the environmental challenges of the modern era (Wendling et al., 2020). Additionally, the economic freedom index, which measures the ability of a country to generate richness and provide a better human development, based on factors such as governmental integrity, labor freedom, tax burden, among others, obtained an unsatisfactory score. Therefore, Brazil occupied 150th place in the global ranking in 2019, and 27th place among American countries regarding this issue, with an overall score lower than the regional and global averages (Heritage Foundation, 2019).

\section{Property Rights and Responsibility}

This component had a good performance (score: 4.2 ). This value is explained by the good performance of its two dimensions: Fishing access rights (4.5) and Harvest rights (4.0). Brown-shrimp fisheries are controlled by limited access, through fishery licenses granted by the Federal Government for vessels of this modality to operate in this region. Licenses can be transferred through a controlled administrative process. These management measures

\footnotetext{
${ }^{1}$ https://epi.yale.edu/epi-results/2020/country/bra
}

are important to mitigate ecological impacts (McConnaughey et al., 2019) and to prevent overcapitalization.

\section{Co-management}

Brown-shrimp fishery had an unsatisfactory average for the Comanagement component (score: 2.4 ), and all dimensions had a similarly low performance (Figure 3). The low participation level of productive chain agents (fishers, skippers, and professionals of the industry) in decision-making processes involving fishery management explain the low performance.

The dimension Leadership and Cohesion (score: 2.0) had the lowest average performance, especially compared to the average of developing countries and of the top 10 fisheries with the best performance (score: 3.37 and 4.5, respectively). Although the professionals involved in shrimp fishery (whether they are shipowners or holders of fishery licenses, such as skippers and other members of the crew) have their own class representatives, organizations levels are inefficient and verticalization predominates in class entities. Therefore, decisions related to management are ultimately centralized in company owners with higher status and higher political and economic clout. Class entities that represent fishers are the most disorganized. They do not have a strong representative authority and, therefore, they have little influence management policies. They are in place nearly exclusively to defend labor issues between workers and companies. The good relationship between fisher class entities and regional or national government agencies is essential for better management of the system and higher levels of governance (Oviedo and Bursztyn, 2017).

This strategy of the industrial elite in keeping the low-tier professional estranged from decisions regarding resources reveals the lack of transparency of everything that occurs concerning 


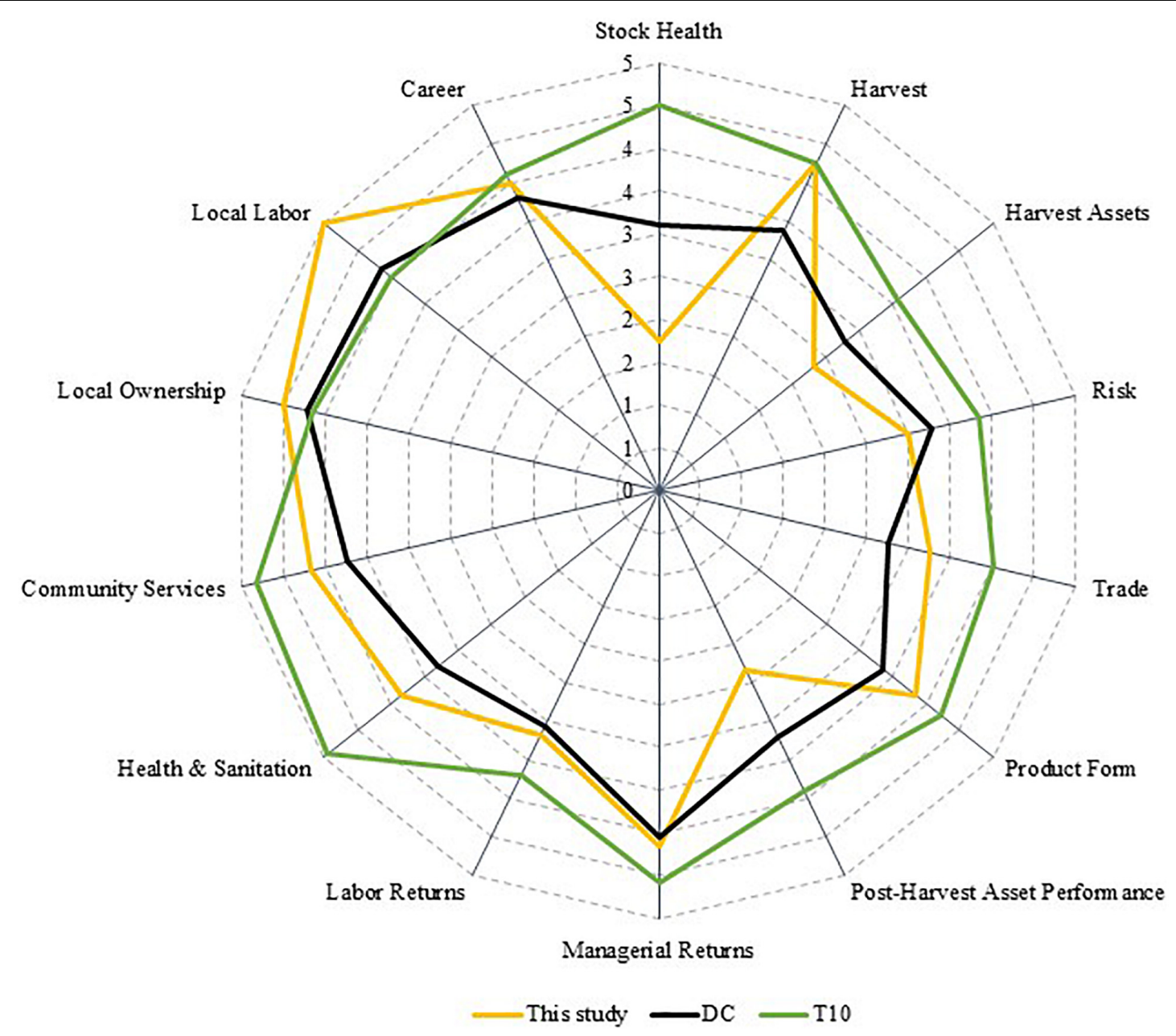

FIGURE 2 | Industrial shrimp fishery input scores (yellow) and the average FPI dataset for developed countries and the average of the top 10 best performing world fisheries. DC - Developed Countries; T10 - Top 10 best performing fisheries.

this activity. It is assumed that a more aware and informed worker might have more arguments to question their superiors in labor relationships. Despite the fact that participation of and the sharing of responsibilities by all stakeholders involved in the process, as well as the strengthening of leaderships, are key attributes to ensure successful fishery management, many productive chain actors of shrimp trawling on the ACS are not aware either of their rights or of the characteristics of the entire process, which thus paves the way for exploratory relations (Berkes, 2009; Bailey et al., 2016; Purcell et al., 2017).

The Gender component (score: 2.3 ) resulted in a low score. The industrial brown-shrimp fishery is a predominantly male activity, with no women onboard the vessels. This condition has been historically bult and is explained by the low hygienesanitary conditions of the vessels, by the long duration of highseas trips (on average, 45 days), by the risks of violence during fishery trips, and by the hardship of the work developed in this fishery modality (Figure 3). This characteristic is common in the Amazon region, as well as in the global fishery sector, which is reflected in the low score also assigned for this dimension in fisheries worldwide (Figure 3). According to FAO, only 12\% of the workers in extractivism sectors are women, and higher participation of females (approximately 50\%) only occurs in the post-harvest sector (FAO, 2020).

Aside from female roles that lie primarily in the processing and trade of fishery products, women are related to terrestrial activities and are indirect key players for a successful fishery, as they manage the homes and the financial resources obtained with this activity, thus ensuring the economic and emotional maintenance of the family, through caregiving activities and domestic chores, among others (Frangoudes and Gerrard, 2018).

\section{Management}

The Management component, related to the success level of fishery management and to governmental financial incentives and subsidies, such as scientific monitoring to ensure sustainable fishery, had an intermediate score (score: 3.3). Some measures, such as closure season or the limit of vessel numbers, were not enough to ensure satisfactory levels of sustainability for this fishery, since despite that, the fishery continues to use 


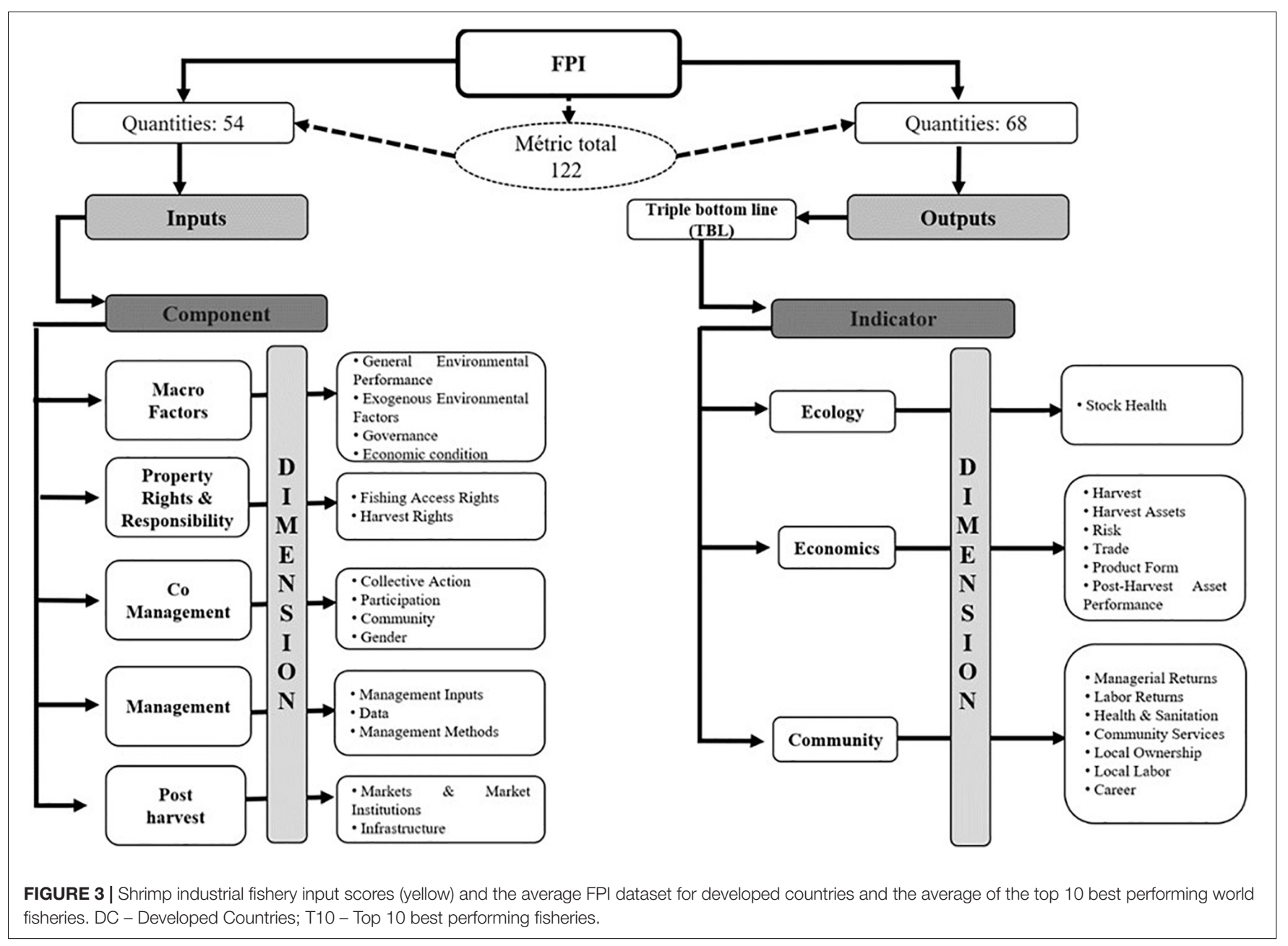

the non-selective trawling technique, remaining a high rate of incidental capture, and the yield and effort are decreasing along the time, showing that the activity does not have enough attractions.

The dimensions Management Methods and Data averaged a score of 3.0, as the data collected on production were not easily accessible and were discontinuous. Even though fleet activity has some punctual scientific monitoring. Aside from incomplete, data were mostly focused on biological data of the target species (with little data on by-catch), and social-economic information, which is as equally important, was not collected (Sena, 2005; Aragão et al., 2015a).

Furthermore, the development of studies in this sector has been facing resistance from agents of the fishery industry, as well as from the processing industry. The entrance of researchers is encumbered by processing companies as the latter are concerned by potential restrictions to current harvest practices. The paucity of data leads to uncertainty regarding the stock status and economic sustainability of the actors, which might compromise the economic and food security of users' dependents, and might increase the chances of overfishing (Bradley et al., 2019).

The access to public policies was analyzed using the metric Level of subsidies. The vessel owners of the shrimp fishery can access to oil subsidy of $25 \%$ for trips of the trawlers. The access to economic subsidies is important to maximize fishery, as it reduces costs, especially in the case of fuel, which is the major variable cost of fishery vessels (Araújo, 2021). On the other hand, these subsidy policies might conceal resource limitations and lead to fleet overcapacity. Economic subsidies might encourage the increase levels of effort, making fishery more attractive economically by reducing costs (Pauly et al., 2002). Therefore, subsidies were not considered a long-term benefit for the activity from the ecological standpoint (Sumaila et al., 2008; Sakai et al., 2019).

\section{Post-harvest}

This component, which evaluates the conditions of fishery product trade, obtained an intermediate performance (score: 3.4). The dimensions Markets and Market Institutions (score: 2.7) helped to reduce the overall score. The southern brownshrimp, which is the target of these fisheries, is predominantly sent to the international market (FAO, 2020), has fixed buyers, and its price is adjusted by foreign demand. This contributed with the low scores found for the metrics Landings Pricing System, Number of Buyers, and Degree of Vertical Integration. The international market primarily benefits from the main economic benefits of this activity and the value added in the 


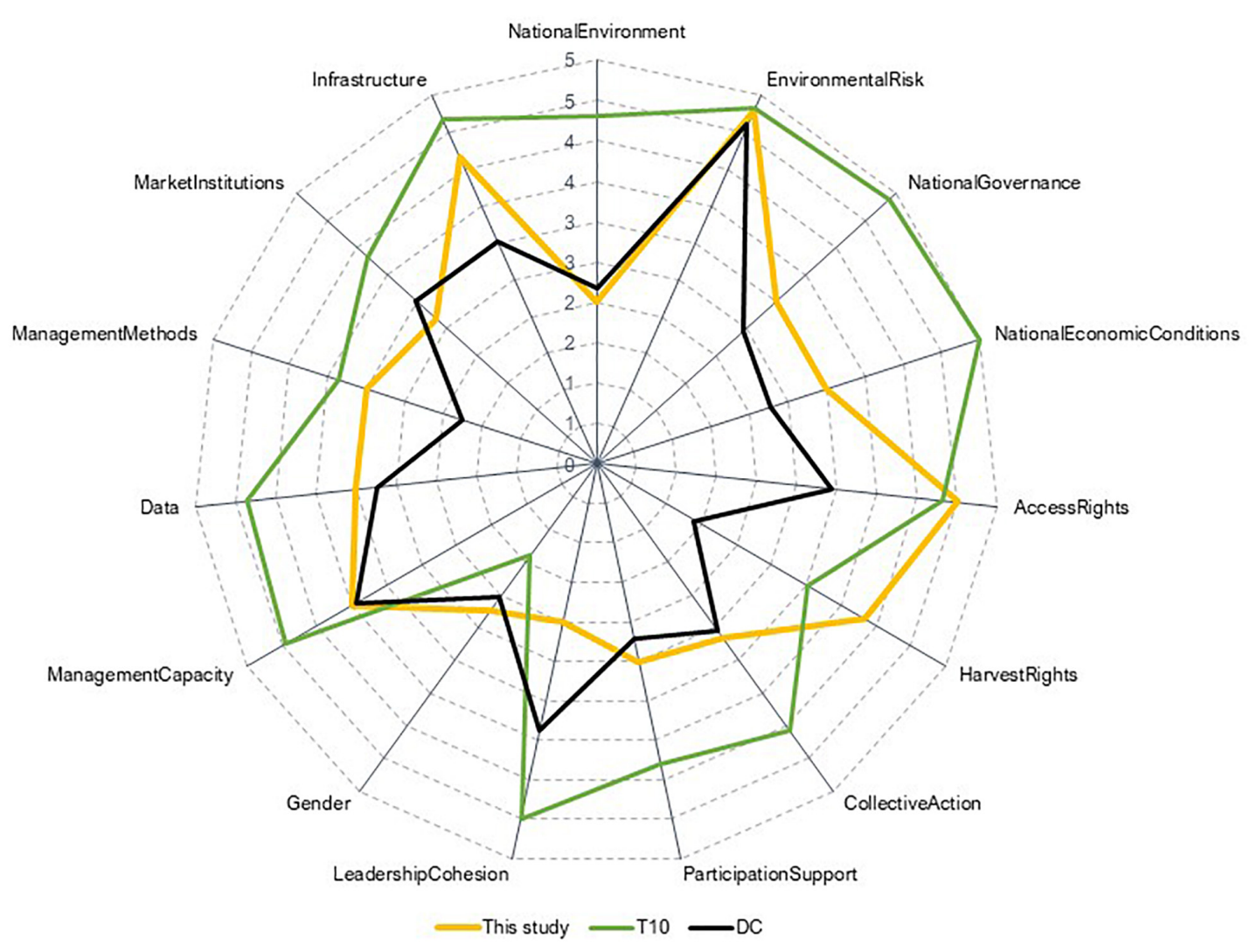

FIGURE 4 | Comparison of TBL output scores for the Shrimp Industrial Fishery and the average FPI dataset of developed countries and the average of the top 10 best performing world fisheries. DC - Developed Countries; T10 - Top 10 best performing fisheries.

product traded. Local actors such as fishers or skippers are the least favored in the production chain. This was considered a negative factor for the social sustainability of this activity (Swartz et al., 2010).

On the other hand, the dimension of Infrastructure resulted in a high score (score: 4.2). The processing companies are well located, have their own unloading ports, good operational structure, access to the power grid, as well as their own energy generators, to ensure the quality of frozen products, in cases of city power supply outages, which are common in Amazon region. They also have good access to paved highways, providing a more feasible distribution flow.

\section{Output Indicators of TBL Ecological Indicator}

Although brown-shrimp stocks are not considered overexploited (Isaac et al., 1992; Aragão et al., 2015a; Peixoto, 2020), the ecological indicator had the worst performance of the entire analysis (score: 1.7), well below the average performance of fisheries in developing countries and of the top 10 fisheries with the best performance (Figure 4; Anderson et al., 2016).

In the case of shrimp fishery on the ACS, the dimension related to ecological factors is closely related to the nature of the activity. Trawling carries unsustainability elements due to the low selectivity of this fishing practice, which is a threat to marine biodiversity, affecting the complex ecological processes in the oceans (Kumar and Deepthi, 2006; Worm et al., 2009), the biota and the ecosystem (Jørgensen et al., 2016; Mazor et al., 2020; Behera et al., 2021).

Although shrimp is abundant and typically an r-strategist (in the sense of Odum, 1983), which renders it a stock resilient to fishing pressure (Adams, 1980; García, 1988; Gillett, 2008), the by-catch, which is incidentally captured in this fishery, represents a drawback to environmental sustainability due to the large amount of organisms discarded (Pérez Roda et al., 2019; FAO, 2020). It is well known that, for each kilo of shrimp, at least $4.3 \mathrm{~kg}$ of other resources are captured, which are not always used (Paiva et al., 2009). Trawl nets harvest at least 201 species as by-catch, especially teleost fishes (Marceniuk et al., 2019) and over 200 invertebrate species (Nóbrega, 2019). There is also the risk of by-catch of species that are deemed vulnerable or endangered, as is the case of some shark and marine turtle species (Kumar and Deepthi, 2006; Lewison et al., 2014; Marceniuk et al., 2019; Peixoto, 2020). These factors reduced the score of ecological metrics.

Additionally, the dynamics of by-catch capture, regarding composition and spatial-temporal variation, is still poorly known as the total catch volumes are not reported (Uhlmann et al., 2014; Branco et al., 2015), which also contributed with the low 
ecological performance. The proximity of the fleet ground area to Amazon coral reefs (Moura et al., 2016) further emphasizes the unsustainability of this trawl fishery concerning ecosystem maintenance, although it is still considered attractive from an economic standpoint (Dias-Neto and Dias, 2015).

Shrimp fishery in the North of Brazil is inserted in the proposal "National Management Plan for the Sustainable Use of Marine Shrimps in Brazil" (Dias-Neto, 2011). This plan proposes the adoption of strategies to avoid by-catch capture, e.g., the use of technological reduction devices such as the so-called BRD (Bycatch Reduction Devices) (Eayrs, 2007). However, this document does not seem to have a significant effect on fishery methods and very few of its objectives have been translated into concrete actions to ensure sustainability, in practice, which might be due to the verticalization in its design.

Devices such as BRDs have been used in shrimp fleet nets in other countries such as Norway, the United States, and Australia (Cattani et al., 2012). From the perspective of operationalizing the use of these devices, FAO and funding agencies in Brazil have supported projects to experiment and disseminate these devices. Although that, the acceptance of BRDs by fishers is still low. Despite the results of scientific experiments that prove that BRD could improve the performance of trawling, vessel owners fear that these devices might decrease yield, which leads to doubts regarding the costs and benefits of this change (O’Neill et al., 2019).

\section{Economic Indicator}

The economic indicator resulted in an intermediate score (Figure 5), and the dimensions Harvest Assets and PostHarvest Asset Performance (score: 2.3 for both of them) contributed with this performance. These dimensions evaluate the historical economic conditions of fishery. In the case of shrimp fishery, there have been historically different scenarios involving production, price behavior, and exportation (COMEX STAT, 2021).

One of the changes about seafood trade is related to changes in the behavior of the global consumer, who has been refusing products derived from fisheries considered unsustainable. The modality of fishery with trawl net, deemed as having low selectivity, has permeated discussions throughout the world, and many countries have banned this activity, as is the case of certain fisheries in Hong Kong (Tao et al., 2018), Italy (Pipitone et al., 2000), Indonesia (Bailey, 1997) and the Netherlands (Bergman et al., 2015), among others.

Changes in the export scenario have already been observed in the industrial fishery of northern Brazil due to the loss of markets that were previously consolidated. This is the case of the United States and European countries such as France, Spain, and Belgium, which were the major importers of the Brazilian brownshrimp until 2017, yet have closed their markets to this product over the last years (COMEX STAT, 2021).

This loss is related to the adoption of new requirements in countries such as the United States, that refuse the purchase of products derived from trawling, which has high rates of discarded by-catch. This country has implemented the Seafood Import Monitoring Program (SIMP), which adopts measures to prevent the entrance of products that are either illegal or of unsustainable origins (Amaral, 2018). The countries that have banned discarded by-catch in their fishery activities, adopt similar stricter criteria regarding their imports. The European Union, for instance, has adopted the mandatory reduction of bycatch in fisheries since 2015 , thus encouraging a higher selectivity in fishery practices to rebuild the stocks affected (Worm et al., 2009; Millán et al., 2014; Gullestad et al., 2015). Hygiene-sanitary conditions of the Brazilian product, especially due to structure of and handling on vessel decks, which lead to higher exposure to contaminations, have also contributed to the reduction in exports.

Therefore, the growing global demand for seafood of sustainable origin, which results from a global tendency toward conscious consumption, encourages certification initiatives and recommendations that have affected the preference of consumers (Belson, 2012). Certifications aim to support sustainability, providing information on production methods and resource origin and represent an attempt to provide visibility and acceptance of products in the international market, even increasing market values (Gutierrez and Thornton, 2014; Duggan and Kochen, 2016). However, there is no evidence that shrimp fisheries in the northern coast of Brazil have been headed toward the same direction.

Thus, to adapt to the changes of the market the ACS shrimp export industry adopt new sales strategies, intended for other markets with lower requirements (Dey et al., 2008). In this way, the industry has found a solution to maintain the activity, without having to perform changes in the production process that could lead to increased costs to improve the quality of the products.

This situation reveals the need for economic investigations to guide public policies for this sector or even to propose changes in how the production system operates. The search for better financial results is the primary cause for fleet behavior, sometimes leading to maximizing economic benefits with the lowest investment possible, a situation that has been occurring with other fisheries throughout the world (FAO, 2014).

From an economic standpoint, the shrimp industry in the ACS has a behavior that might be defined as "imperfect competition." This means that, in practice, there are barriers to the entry of new companies in this sector, due to the level of tradition and experience that this activity requires (Pindyck and Rubinfeld, 2013). This decreases natural competition among companies (Dereli, 2015).

The elite of the sector has power to force public policies of interest in the productive sector, as is the case of diesel oil subsidies, which help reduce operational costs of this fishery, favoring the entrepreneur but not the sustainability of the activity. Moreover, the benefit gained with this subsidy is not necessarily passed on to end consumers, due to the product's high demand, which prevents prices from dropping (Graça-Lopes, 1997). This is evident in the case of the brown-shrimp, as it is an asset of high commercial value, mainly accessible to higher-income consumers (Swartz et al., 2010).

\section{Community Indicator}

The Community indicator performance was high (score: 4.0), higher than the average of fisheries in developing countries and 


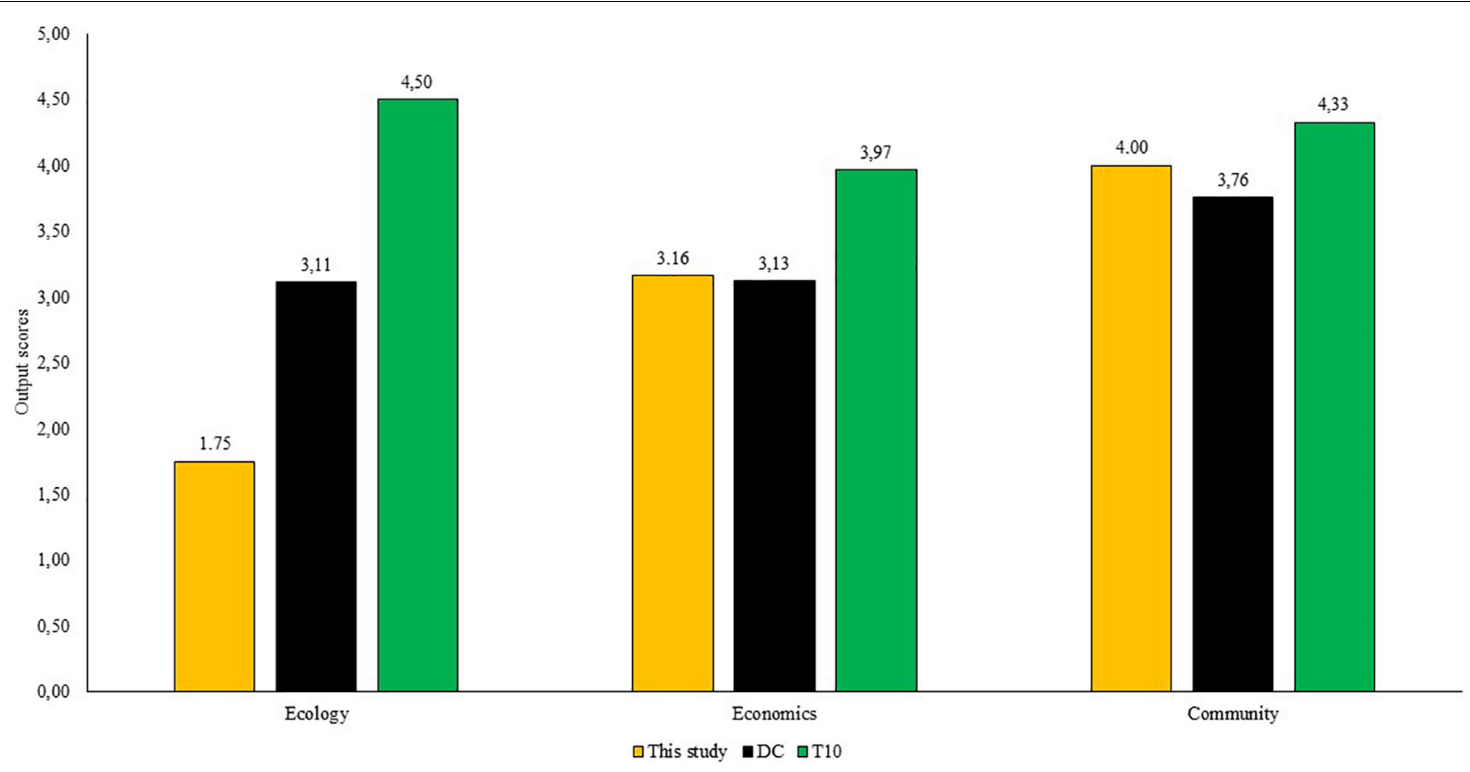

FIGURE 5 | Comparison of TBL (three bottom line) output scores for the Shrimp Industrial Fishery (yellow), the average FPI dataset of developing countries (black) and the average of the top 10 best performing world fisheries (green).

the 10 top fisheries with the best performance (Figure 5). This result is particularly associated to the social-economic conditions that the industrial brown shrimp fishery provides to its actors. The professionals involved in the harvest and processing shrimp industrial sectors have good, differentiated economic benefits, compared to other regional fisheries, such as those of the small scales fishery (Isaac et al., 2009).

The trawling fleet works with salaried workers, they receive labor rights, such as vacations, leaves and insurances, unlike small-scale fishers, who are autonomous. In order to be contracted, both shrimp fishers and workers of processing factory must have some qualification; therefore, this is a group with recognized experience.

Additionally, there is a hierarchy in labor division, which allows establishing a certain "professional career path," which starts with fisher and scales up to master, which ensures prospects of professional valuation and higher benefits in wages and in work commissions.

Payments in the fishery activity are performed both through a fixed salary and through a share in production results, with bonuses and commissions, which encourage the crew to increase yield and seek a higher commercial value shrimp (Kessler, 2009; Guillen et al., 2019).

The social-economic benefits of fisheries allow for nearly all agents in the sector to have permanent residence in the city of Belém, capital of the state of Pará, considered the second most developed city in the northern region of Brazil (Instituto Brasileiro de Geografia e Estatística. Censo Demográfico [IBGE], 2010). This promotes access to community services, such as healthcare assistance, opportunities for formal education of children, job opportunities, and opportunities for income generation for other members of the family, as well as other public policies that are more accessible to city dwellers.
These conditions increase life quality and the well-being of the actors of this activity and that of their family members (Teixeira et al., 2016).

Although there are many productive chain agents in shrimp fishery, the social and political dimensions of the FPI community obtained good results in general, which also results from the legal requirements set in place to establish a fishery company, as well as the organization of base groups, which aim to ensure labor rights (Pessanha and Artur, 2013). Social security collection in formal jobs also ensures them pension benefits, such as retirement and health insurance (Brasil, 2002).

These are the reasons why the industrial brown-shrimp fishery scenario in the ACS had a good performance in the community dimension, unlike other small-scale, regional, and national fisheries, which have precarious labor relationships and little or no access to public policies (Marschke et al., 2019).

Even seeing the good performance of the community, especially with regard to the benefits granted through the formalization of the labor relationship through salaried employment in relation to smaller-scale fisheries, this factor does not mean greater participation of workers in fisheries management, something that was visualized in the dimension of Leadership and Cohesion that shows an inferior performance.

Figure 5 shows that the FPI results of the industrial fishery in the northern Brazilian coast are lower regarding ecological and economic indicators, compared to the average of fisheries conducted in developing countries and to the top 10 fisheries with the best FPI performance. It is worth emphasizing that the ecological indicator obtained the worst indicators, owing to the conditions under which the fishery occurs in the trawling modality, which is considered to have low selectivity (Allen et al., 2017; Bomfim et al., 2019). The 
community indicators (4.00) obtained a higher score compared to the performance observed in developing countries, yet still lower than the average of the top 10 fisheries with the best performance, with higher structure provided for the fishery. Nevertheless, this score indicates that better conditions to supply the product to the international market (which brings an important return for the actors involved in this activity) are still necessary.

\section{FINAL CONSIDERATIONS}

Despite the challenges in obtaining environmental data and information on the economic and political performance of fishery management, the application of the FPI methodology allowed us to visualize the critical aspects of this activity, especially the co-management factor (among inputs) and the ecological factor (among outputs), as well as strengths such as Property Rights \& Responsibility (among inputs) and the community factor (among outputs), which obtained the best scores. These results outline a current scenario that helps formulate proposals for changes to improve the performance of this activity regarding the environment and the harvest and post-harvest sectors (McCluney et al., 2019).

Our conclusion is that the activity is developed under poor sustainability conditions according to the set of ecological indicators, due mostly to the large impact on by-catch diversity and to the low selectivity of trawl nets.

The repercussions derived from the low selectivity of this fishery directly affect the other indicators analyzed by the FPI methodology, as they are directly related to each other.

The new market requirements, which result from changes in consumer demands, lead to the search for innovations that allow an adjustment of the products of these fisheries, in order to attract a public who seeks indicators of biodiversity conservation and the maintenance of life quality on the planet. Unfortunately, pleas for changes in fishery techniques have appeared outside the sector without the effect required to lead to the desired local adjustment.

The ecological appeal affects the economic dimensions, thus affecting the competitiveness of the traded products, thus contributing to the less favorable image of the sector. This limits the prices practised, affecting the profitability of the entire productive chain. This scenario, along with the economic crises in the country, has resulted in the closing of companies, unemployment, development of exploratory labor relations, lower payments, and the worsening of conflicts in the sector.

The plea to create ecosystem-based management mechanisms has increased globally, aiming to ensure the continuous provision of fishery products for present and future generations. A highlight among these initiatives are the projects for certification or ecological labeling, which enable to relieve poverty, increase income and food security in developing countries, ensure the long-term availability of fishes, and even improve their added value and increase trade (United Nations Environment Programme [UNEP], 2009; Deutsch et al., 2011).

Therefore, despite the good FPI results of the Community dimension, Amazon brown shrimp fisheries are in need of an urgent intervention so that the impacts on by-catch are mitigated.
We believe strategies for the education on and diffusion of this study results must be implemented, in order to marshal higher articulation and better dialogue between the social actors involved, enabling the rise of a culture of conscious consumption and sustainable catch, with the required adjustments for the activity to obtain higher sustainability levels. Cases of other fisheries in Brazil, such as trawling in the south of the country, might help convince the agents to take on these changes (Cattani et al., 2012; Schroeder et al., 2016). Other national fisheries have been following the path to sustainability in order to attract a more demanding market. One such example is the industrial snapper (L. purpureus) fishery, which has already been discussing rules designed to rebuild stocks (Freire, 2019).

Shrimp trawling in the northern region of Brazil has been the object of contention (Medeiros et al., 2013). That is why it is important that the participation of agents in the sector is equitative so that everyone feels responsible for the decision-making process regarding management. Furthermore, continuous monitoring of fishery results and of the effectiveness of this management is essential (and this is a dynamic process). Additionally, data should be made public to better allow further analyses and the disclosure of results to every public.

\section{DATA AVAILABILITY STATEMENT}

The original contributions presented in the study are included in the article/Supplementary Material, further inquiries can be directed to the corresponding author.

\section{AUTHOR CONTRIBUTIONS}

All authors listed have made a substantial, direct, and intellectual contribution to the work, and approved it for publication.

\section{FUNDING}

This study was financed in part by the Coordenação de Aperfeiçoamento de Pessoal de Nível Superior - Brasil (CAPES) Finance Code 001.

\section{ACKNOWLEDGMENTS}

We are grateful to the Project "Sustainable Management of Bycatch in Latin America and Caribbean Trawl Fisheries REBYC II," under development by FAO since 2015, to the project "Rede cooperativa multidisciplinar para subsidiar o manejo da pesca dos estoques de camarões da região Norte e Nordeste do Brasil com foco ecossistêmico" Process 445766/2015$8 \mathrm{MCTI} / \mathrm{MPA} / \mathrm{CNPq}$.

\section{SUPPLEMENTARY MATERIAL}

The Supplementary Material for this article can be found online at: https://www.frontiersin.org/articles/10.3389/fmars.2022. 801758/full\#supplementary-material 


\section{REFERENCES}

Adams, P. B. (1980). Life history patterns in marine fishes and their consequences for management. Fish. Bull. 78, 1-12.

Allen, S. J., Pollock, K. H., Bouchet, P. J., Kobryn, H. T., McElligott, D. B., Nicholson, K., et al. (2017). Preliminary estimates of the abundance and fidelity of dolphins associating with a demersal trawl fishery. Sci Rep. 7:4995. doi: 10.1038/s41598-017-05189-0

Amaral, S. (2018). Desafios e Oportunidades Para Exportação de Produtos Brasileiros aos Estados Unidos. Rio de Janeiro :FUNCEX.

Anderson, J. L., Anderson, C. M., Chu, J., and Meredith, J. (2016). Fishery Performance Indicators Manual (Version 1.3). Available online at: http://isfs. institute.ifas.ufl.edu/projects/new-metrics/fpi-manual. (acessado on jun 20, 2020)

Anderson, J. L., Anderson, C. M., Chu, J., Meredith, J., Asche, F., Sylvia, G., et al. (2015). The Fishery Performance Indicators: A Management Tool for Triple Bottom Line Outcomes. PLoS One 10:e0122809. doi: 10.1371/journal. pone.0122809

Aragão, J. A., Cintra, I. H., Silva, K. C., and Vieira, I. J. A. (2001). A explotação camaroneira na costa norte do Brasil. Bol. Técnico Cient. CEPNOR. Belém. 1, $11-44$.

Aragão, J. A. N., Silva, K. C. A., and Cintra, I. H. A. (2015a). Situação da pesca de camarões na plataforma continental amazônica. Acta Fish. Aquat. Res. 3, 61-76. doi: 10.2312/ActaFish.2015.3.2.61-76

Aragão, J. A. N., Silva, K. C. A., and Cintra, I. H. A. (2015b). Pesca industrial do camarão-rosa na plataforma continental Amazônica: aspectos da dinâmica da população, avaliação do estoque e influência dos parâmetros ambientais. Acta Fish. Aquat. Res. 3, 77-90. doi: 10.2312/ActaFish.2015.3.1.77-90

Araújo, J. A. (2021). Economia e Sustentabilidade da Pesca Industrial do Camarão Rosa Penaeus subtilis (Pérez-Farfante, 1967) na Plataforma Norte do Brasil. Postgraduate program in aquatic ecology and fisheries. Ph.D thesis, Belém: NEAP-UFPA.

Asche, F., Garlock, T. M., Anderson, J. L., Bush, S. R., Smith, M. D., Anderson, C. M., et al. (2018). Três pilares da sustentabilidade na pesca. Proc. Natl. Acad. Sci. U.S.A. 78:201807677. doi: 10.1073/pnas.1807677115

Bailey, C. (1997). Lessons from Indonesia’s 1980 trawler ban. Mar. Pol. 21, 225-235. doi: 10.1016/S0308-597X(97)00003-1

Bailey, M., Bush, S., Oosterveer, P., and Larastiti, L. (2016). Fishers, Fair Trade, and finding middle ground. Fish. Res. 182, 59-68. doi: 10.1016/j.fishres.2015.11. 027

Barthem, R. B., and Schwassmann, H. (1994). The Amazon river influence over the seasonal displacement of the salty wedges in Tocantins estuary, Brazil, 1983-1985. Bol. Mus.Para. Emilio Goeldi. Ser. Zool. 10, 119-130.

Behera, P. R., Ghosh, S., Ramulu, K. S., Menon, M., Jishnudev, M. A., and Satish Kumar, M. (2021). The Cost of Fishing on Juveniles of Finfish and Shellfish: assessment of Economic Impacts of Trawl Juvenile by-Catch along the Coast of North Andhra Pradesh. India. Thalassas 37, 409-426. doi: 10.1007/s41208-02100290-8

Belson, J. (2012). Ecolabels: ownership, use, and the public interest. J. Intellect. Prop. Law Pract. 7, 96-106. doi: 10.1093/jiplp/jpr198

Bentes, B., Aragão, J. A. N., Freire, J. L., Lutz, I. A. F., and Gomes, T. (2017). Documento técnico sobre a situação atual das pescarias do pargo na Região Norte do Brasil. North Brazilian Caribbean red snapper FIP Reports. Available online at: https://fisheryprogress.org/sites/default/files/indicators-documents/Diag\% 20T\%C3\%89C\%20FIP\%20PARGO\%20JULHO\%202017.pdf. (accessed on Feb 1, 2020).

Bentes, B., Isaac, V. J., Espírito-Santo, R. V., Frédou, T., Almeida, M. C., Mourão, K. R., et al. (2012). Multidisciplinary approach to identification of fishery production systems on the northern coast of Brazil. Biota. Neotrop. 12, 81-92. doi: 10.1590/S1676-06032012000100006

Bergman, M. J. N., Ubels, S. M., Duineveld, G. C. A., and Meesters, E. W. G. (2015). Effects of a 5-year trawling ban on the local benthic community in a wind farm in the Dutch coastal zone. ICES J. Mar. Sci. 72, 962-972. doi: 10.1093/icesjms/fsu193

Berkes, F. (2009). Evolution of co-management: Role of knowledge generation, bridging organizations and social learning. J. Environ. Manage. 90, 1692-1702. doi: 10.1016/j.jenvman.2008.12.001
Bomfim, A. C., Farias, D. S. D., Morais, I. C. C., Rossi, S., Gavilan, S. A., and Silva, F. J. L. (2019). The impact of shrimp trawl bycatch on fish reproduction in northeastern Brazil. Biota. Amazônica. Macapá 9, 37-42. doi: 10.18561/21795746/biotaamazonia.v9n1p37-42

Bradley, D., Merrifield, M., Miller, K. M., Lomonico, S., Wilson, J. R., and Gleason, M. G. (2019). Opportunities to improve fisheries management through innovative technology and advanced data systems. Fish Fisheries 20, 564-583. doi: $10.1111 /$ faf.12361

Branco, J. O., Freitas Júnior, F., and Christoffersen, M. L. (2015). Fauna de captura acidental da pesca de arrasto do camarão-do-mar no Estado de Santa Catarina, sul do Brasil. Biota Neotrop. 15, 165-175. doi: 10.1590/S167606032013000100019

Brasil (1987). Portaria SUDEPE $n^{\circ} \mathrm{N}-11$ de 13 de maio de 1987. Available online at: https://www.icmbio.gov.br/cepsul/images/stories/legislacao/Portaria/1987/ p_sudepe_11_n_1987_areaexclusaopescaarrasto_pa_ma_am_ap.pdf (accessed on May, 292020$)$

Brasil (2002). Ministério da Previdência e Assistência Social. Regime Geral de Previdência Social: consolidação da legislação. Brasília: MPAS.

Brasil (2017). Portaria Interministerial $n^{\circ}$ 75, de 20 de dezembro de 2017. Available online at: https://www.gov.br/agricultura/pt-br/assuntos/aquicultura-e-pesca/ legislacao/defesos/portaria-interministerial-mdic-mma-no-75_12_2017.pdf/ view (accessed on May 29, 2020)

Brasil (2018). Portaria Interministerial MDIC/MMA $n^{\circ} 15$, de 10 de janeiro de 2018. Available online at: https:/www.gov.br/agricultura/pt-br/assuntos/ aquicultura-e-pesca/legislacao/arrasto/portaria-mdic-mma-no-15-de-10-012018.pdf/view (accessed on May, 29 2020)

Cattani, A. P., Bernardo, C., Medeiros, R. P., Santos, L. O., and Spach, H. L. (2012). Avaliação de dispositivos para redução da ictiofauna acompanhante na pesca de arrasto dirigida ao camarão sete-barbas. Bol. Inst. Pesca. 38, 333-348.

Chu, J., Garlock, T. M., Sayon, P., Asche, F., and Anderson, J. L. (2017). Impact evaluation of a fisheries development project. Mar. Policy 85, 141-149. doi: 10.1016/j.marpol.2017.08.024

Cintra, I. H. A., Aragão, J. A. N., and Silva, K. C. A. (2004). Maturação gonadal do camarão-rosa, Farfantepenaeus subtilis (Pérez Farfante, 1967), na região norte do Brasil. Bol. Téc. Cient. Cepnor 4, 21-29.

COMEX STAT (2021). COMEX STAT - SECEX - Portal de estatísticas de comércio exterior do Brasil. Available online at: http://comexstat.mdic.gov.br/pt/home (accessed March 20, 2021).

Dereli, D. D. (2015). Innovation Management in Global Competition and Competitive Advantage. Proc. Soc. Behav. Sci. 195, 1365-1370. doi: 10.1016/j. sbspro.2015.06.323

Deutsch, L., Troell, M., Limburg, K., and Huitric, M. (2011). "Global Trade of Fisheries Products-implications for marine ecosystems and their services," in Ecosystem Services and Global Trade of Natural Resources: Ecology, Economics and Policies, ed. T. Köllner (London, UK: Routledge), 120-147.

Dey, M. M., Garcia, Y. T., Praduman, K., Piumsombun, S., Haque, M. S. H., Li Luping Radam, A., et al. (2008). Demand for fish in Asia: a cross-country analysis. Aust. J. Agric. Res. Econ. 52, 321-338. doi: 10.1111/j.1467-8489.2008. 00418.x

Dias-Neto, J. (2011). Proposta De Plano Nacional De Gestão Para O Uso Sustentável De Camarões Marinhos Do Brasil. Brasília: MMA.

Dias-Neto, J., and Dias, J. F. O. (2015). O Uso da Biodiversidade Aquática no Brasil: Uma Avaliação com foco na pesca. Brasília: IBAMA.

Duggan, D. E., and Kochen, M. (2016). Small in scale but big in potential: Opportunities and challenges for fisheries certification of Indonesian smallscale tuna fisheries. Mar. Pol. 67, 30-39. doi: 10.1016/j.marpol.2016.01.008

Eayrs, S. (2007). A guide to bycatch reduction in tropical shrimp-trawl fisheries. Revised edition. Rome: FAO.

Eggert, H., Anderson, C. M., Anderson, J. L., and Garlock, T. M. (2021). Assessing global fisheries using Fisheries Performance Indicators: Introduction to special section. Mar. Policy 125:104253. doi: 10.1016/j.marpol.2020. 104253

FAO (2014). The State of World Fisheries and Aquaculture 2014: Opportunities and challenges. Rome: FAO.

FAO (2018). The State of World Fisheries and Aquaculture 2018 - Meeting the sustainable development goals. Rome: FAO. 
FAO (2020). The State of World Fisheries and Aquaculture - 2020 (SOFIA). Food and Agriculture Organization of the United Nations. Rome: FAO Fisheries and Aquaculture Department.

Frangoudes, K., and Gerrard, S. (2018). (En)Gendering Change in Small-Scale Fisheries and Fishing Communities in a Globalized World. Maritim. Stud. 17, 117-124. doi: 10.1007/s40152-018-0113-9

Frédou, F. L., Mourão, K., Barbosa, C., Almeida, O., Rivero, S., and Thompson, R. (2009). Caracterização das pescarias industriais da costa norte do Brasil. Paper NAEA 237, 1-33.

Freire, J. (2019). Pesca, reprodução e crescimento de Lutjanus purpureus (Lutjanidae-Perciformes) no recife amazônico. Postgraduate program in aquatic ecology and fisheries. Ph.D thesis, Belém: NEAP-UFPA.

García, S. (1988). "Tropical Penaeid Prawns," in Fish Population Dynamics: the Implications for Management, ed. J. A. Gulland (Sydney, NSW), 219-249. Available online at: https://core.ac.uk/download/pdf/39868106.pdf (accessed 22 February, 2021).

Garcia, S. M., Zerbi, A., Aliaume, C., Do Chi, T., and Lasserre, G. (2003). The ecosystem approach to fisheries. Issues, terminology, principles, institutional foundations, implementation and outlook FAO Fisheries Technical Paper. No. 443. Rome: FAO.

Gillett, R. (2008). Global study of shrimp fisheries. FAO Fisheries Technical Paper No 475. Rome: FAO.

Graça-Lopes, R. (1997). Gerenciamento pesqueiro. Retrospectiva dos Serviços de Pesca da Secretaria de Agricultura e Abastecimento e o Jubileu de Prata do Instituto de Pesca. São Paulo: Instituto de Pesca, 77-87.

Guillen, J., Natale, F., Carvalho, N., Casey, J., Hofherr, J., Druon, J., et al. (2019). Global seafood consumption footprint. Ambio 48, 111-122. doi: 10.1007/ s13280-018-1060-9

Gullestad, P., Blom, G., Bakke, G., and Bogstad, B. (2015). The "Discard Ban Package": Experiences in efforts to improve the exploitation patterns in Norwegian fisheries. Mar. Pol. 54:1e9. doi: 10.1016/j.marpol. 2014.09.025

Gutierrez, A., and Thornton, T. (2014). Can consumers understand sustainability through seafood eco-labels? A US and UK case study. Sustainability 6, 81958217. doi: $10.3390 /$ su6118195

Hall, M. A., Alverson, D. L., and Metuzals, K. I. (2000). By-catch: Problems and Solutions. Mar. Poll. Bull. 41, 204-219. doi: 10.1016/S0025-326X(00)00111-9

Heller, C. (1862). Beitrage zur naheren Kentniss der Macrouren. Sitzungsberichte der Mathematisch-Naturwissenschaftlichen Classe der Kaiserlichen Akademie der Wissenschaften. Wien 45, 389-426.

Heritage Foundation (2019). Index of Economic Freedom. Available online at: https: //www.heritage.org/. (Accessed on Dec 28, 2019)

Holthuis, L. B. (1980). FAO Species Catalogue. Vol. 1. Shrimps and prawns of the world. An annotated catalogue of species of interest to fisheries. FAO Fish. Synop, Vol. 125. Rome: FAO.

Instituto Brasileiro de Geografia e Estatística. Censo Demográfico [IBGE] (2010). Resultados gerais da amostra. Rio de Janeiro: IBGE.

Isaac, V. J., Dias Neto, J., and Damasceno, F. G. (1992). Camarão-rosa da costa norte. IBAMA 1, 1-187.

Isaac, V. J., and Ferrari, S. F. (2017). Assessment and management of the North Brazil Shelf Large Marine Ecosystem. Env. Devel. 22, 97-110. doi: 10.1016/j. envdev.2016.11.004

Isaac, V. J., Santo, R. V. E., Bentes, B., Frédou, F. L., Mourão, K. R. M., and Frédou, T. (2009). An interdisciplinary evaluation of fishery production systems off the state of Pará in North Brazil. J. Appl. Ichth. 25, 244-255. doi: 10.1111/j.14390426.2009.01274.x

Jørgensen, L. L., Ljubin, P., Thangstad, T. H., and Certain, G. (2016). Vulnerability of megabenthic species to trawling in the Barents Sea. ICES J. Mar. Sci. 73, 84-97. doi: 10.1093/icesjms/fsv107

Kaschner, K., Kesner-Reyes, K., Garilao, C., Segschneider, J., Rius-Barile, J., Rees, T., et al. (2019). AquaMaps: Predicted Range Maps for Aquatic Species www.aquamaps.org, Version 10/2019.

Kessler, I. (2009). "Remuneration systems," in Managing Human Resources: Personnel Management in Transition, eds S. Bach, M. R. Edwards (Oxford: Blackwell Publishing), 317-345.

Kumar, A. B., and Deepthi, G. R. (2006). Trawling and by-catch: implications on marine. Curr. Sci. 90, 922-931.
Latreille, P. A. (1817). Nouveau Dictionnaire d'Histoire Naturelle appliquée aux Arts, \&c. Edinb. Med. Surg. J. 25. 152-156.

Lewison, R. L., Crowder, L. B., Wallace, B. P., Moore, J. E., Cox, T., Zydelis, R., et al. (2014). Global Patterns of Marine Mammal, Seabird, and Sea Turtle Bycatch Reveal TaxaSpecific and Cumulative Megafauna Hotspots. PNAS 111, 5271-5276. doi: 10.1073/pnas.1318960111

Maia, B. P., Nunes, Z. M. P., Holanda, F. C. A. F., Silva, V. H. S., and Silva, B. B. (2016). Gradiente latitudinal da beta diversidade da fauna acompanhante das pescarias industriais de camarões marinhos da costa Norte do Brasil. Biota Amaz. 6, 31-39. doi: 10.18561/2179-5746/biotaamazonia.v6n1p31-39

Mansfield, B. (2011). “"Modern” industrial fisheries and the crisis of overfishing," in Global Political Ecology, 1st Edn, eds R. Peet, P. R. Robbins, and M. J. Watts (London: Routledge), 84-99.

Marceniuk, A. P., Rotundo, M. M., Caires, R. A., Cordeiro, A. P. B., Wosiacki, W. B., Oliveira, C., et al. (2019). The bony fishes (Teleostei) caught by industrial trawlers off the Brazilian North coast, with insights into its conservation. Neotrop. Ichthyol. 17:e180038. doi: 10.1590/1982-0224-20180038

Marschke, M., Campbell, D., and Armitage, D. (2019). Precarious livelihoods: Examining the inter. People Nat. 2, 152-162. doi: 10.1002/pan3.10061

Martins, D., Camargo-Zorro, M., Souza Filho, P. W. M., Cintra, I. H. A., and Silva, K. C. A. (2015). Spatial distribution of southern brown shrimp (Farfantepenaeus subtilis) on the Amazon continental shelf: a fishery, marine geology and GIS integrated approach. Braz. J. Oceanogr. 63, 397-406. doi: 10.1590/S167987592015090106304

Mazor, T., Pitcher, C. R., Rochester, W., Kaiser, M. J., Hiddink, J. G., Jennings, S., et al. (2020). Trawl fishing impacts on the status of seabed fauna in diverse regions of the globe. Fish Fish. 00, 01-15. doi: 10.1111/faf.12506

McCluney, J. K., Anderson, C. M., and Anderson, J. L. (2019). The fishery performance indicators for global tuna fisheries. Nat. Comm. 10:1641. doi: 10.1038/s41467-019-09466-6

McConnaughey, R. A., Hiddink, J. G., Jennings, S., Pitcher, C. R., Kaiser, M. J., Suuronen, P., et al. (2019). Choosing best practices for managing impacts of trawl fishing on seabed habitats and biota. Fish Fish 21:faf.12431 319-337.

Medeiros, R. P., Guanais, J. H. D. G., Santos, L. O., and Spach, H. L. (2013). Estratégias para redução da fauna acompanhante na frota artesanal de arrasto de camarão sete-barbas: perspectivas para gestão pesqueira. Boletim. Inst. Pesca São Paulo 39, 339-358.

Millán, J. M. B., Quetglas, A. C., Rodriguez, M. G., Jiménez, T. G., and Aguilar, M. G. (2014). The Obligation to Land All Catches - Consequences for the Mediterranean: In-Depth Analysis. Policy Department B: Structural and Cohesion Policies. Belgium: European Parliament.

Ministério da Pesca e Aquicultura [MPA] (2011). Boletim estatístico da pesca e aquicultura 2011. Brasilia: MPA.

Moura, R. L., Amado-Filho, G. M., Moraes, F. C., Brasileiro, P. S., Salomon, P. S., Mahiques, M. M., et al. (2016). extensive reef system at the Amazon River mouth. Sci. Adv. 2:e1501252. doi: 10.1126/sciadv.1501252

Nittrouer, A., and DeMaster, D. J. (1996). The amazon shelf setting: tropical, energetic, and influenced by a large river. Cont. Shelf Res. 16, 553-573. doi: 10.1016/02784343(95)00069-0

Nóbrega, P. S. V. (2019). Diversidade e relações ecológicas de invertebrados capturados em uma pesca camaroeira tropical. Postgraduate program in aquatic ecology and fisheries. Ph.D thesis, Belém: NEAP-UFPA.

Odum, E. P. (1983). Ecologia. Rio de Janeiro: Guanabara Koogan.

O'Neill, F. G., Feekings, J., Fryer, R. J., Fauconnet, L., and Afonso, P. (2019). "Discard Avoidance by Improving Fishing Gear Selectivity: Helping the Fishing Industry Help Itself," in The European Landing Obligation, eds S. Uhlmann, C. Ulrich, and S. Kennelly (Berlin: Springer), 279-296. doi: 10.1007/978-3-03003308-8_14

Oviedo, A. F. P., and Bursztyn, M. (2017). Centralization and Fisheries Management in the Brazilian Amazon: resource rights and accountability. Ambiente Soc. 20, 169-190. doi: 10.1590/1809-4422asoc0029r1v2042017

Paiva, K. S., Aragão, J. A. N., Silva, K. C. A., and Cintra, I. H. A. (2009). A fauna acompanhante da pesca industrial do camarão-rosa na plataforma continental norte brasileira. Bol. Téc. Cient. Cepnor. 9, 25-42.

Pauly, D., Christensen, V., Guénette, S., Pitcher, T., Sumaila, U., Walters, C., et al. (2002). Towards sustainability in world fisheries. Nature 418, 689-695. doi: 10.1038/nature01017 
Pauly, D., and Zeller, D. (2016). Catch reconstructions reveal that global marine fisheries catches are higher than reported and declining. Nat. Commun. 7:10244. doi: $10.1038 /$ ncomms 10244

Peixoto, U. (2020). Pesca industrial do Camarão Rosa (Penaeus Subtilis) na Costa Norte do Brasil: Uma abordagem ecológica para os impactos da Pesca. Postgraduate program in aquatic ecology and fisheries. Ph.D thesis, Belém: NEAP-UFPA.

Peixoto, U. I., Bentes, B., Andrade, H. A., and Isaac, V. J. (2021). Length-based assessment of southern brown shrimp stock from trawl fisheries on the Amazon Continental Shelf. Res. Soc. Dev. 10:e44410817394. doi: 10.33448/rsd-v10i8. 17394

Perez Farfante, I. (1967). A new species and two new subspecies of shrimp of the genus Penaeus form western Atlantic. Proc. Biol. Soc. Wash 80, 83-100.

Pérez-Farfante, I. (1969). Western Atlantic shrimps of genus Penaeus. Fish. Bull. 67, 461-591.

Perez Farfante, I., and Kensley, B. F. (1997). Penaeids and Sergestoid Shrimps and Prawns of the World: Keys and Diagnoses for the Families and Genera. Paris: Muséum national d'Histoire naturelle.

Pérez Roda, M. A., Gilman, E., Huntington, T., Kennelly, S. J., Suuronen, P., Chaloupka, M., et al. (2019). A third assessment of global marine fisheries discards. FAO Fisheries and Aquaculture Technical Paper No 633. Rome: FAO.

Pessanha, L. G. F., and Artur, K. (2013). Direitos trabalhistas e organização dos trabalhadores num contexto de mudanças no mundo do trabalho: efeitos sobre os trabalhadores da saúde. Ciênc. Saúde Coletiva. 18, 1569-1580. doi: 10.1590/ S1413-81232013000600009

Pindyck, R. S., and Rubinfeld, D. L. (2013). Microeconomia. 8 Edn. São Paulo: Pearson Prentice Hall.

Pipitone, C., Badalamentia, F., D’Anna, G., and Patti, B. (2000). Fish biomass increase after a four-year trawl ban in the Gulf of Castellammare (NW Sicily, Mediterranean Sea). Fish. Res. 48, 23-30. doi: 10.1016/S0165-7836(00)00114-4

Purcell, S. W., Crona, B. I., Lalavanua, W., and Eriksson, H. (2017). Distribution of economic returns in small-scale fisheries for international markets: a valuechain analysis. Mar. Pol. 86, 9-16. doi: 10.1016/j.marpol.2017.09.001

Rindorf, A., Dichmont, C. M., Levin, P. S., Mace, P., Pascoe, S., Prellezo, R., et al. (2016). Food for thought: pretty good multispecies yield. ICES J. Mar. Sci. 74, 475-486. doi: 10.1093/icesjms/fsw071

Russo, T., Bitetto, I., Carbonara, P., Carlucci, R., D’Andrea, L., Facchini, M. T., et al. (2017). A Holistic Approach to Fishery Management: evidence and Insights from a Central Mediterranean Case Study (Western Ionian Sea). Front. Mar Sci. 4:193. doi: 10.3389/fmars.2017.00193

Sakai, Y., Yagi, N., and Sumaila, U. R. (2019). Fishery subsidies: the interaction between science and policy. Fish. Sci. 85, 439-447. doi: 10.1007/s12562-01901306-2

Schroeder, R., Bottene, B. R., Sant Ana, R., Wahrlich, R., and Queirolo, D. (2016). Uso do dispositivo excludente de tartarugas (TED) na pesca de arrasto do camarão-rosa no sul do Brasil. Lat. Amer. J. Aqua. Res. 44, 1123-1129. doi: 10.3856/vol44-issue5-fulltext-21

Sena, A. L. S. (2005). Trabalho e trabalhadores da pesca industrial no Pará face à metamorfose do capital. Núcleo de Altos Estudos Amazônicos. Belém: NAEA.

Sumaila, U. R., Teh, L., Watson, R., Tyedmers, P., and Pauly, D. (2008). Fuel price increase, subsidies, overcapacity, and resource sustainability. ICES J. Mar. Sci. 65, 832-840. doi: 10.1093/icesjms/fsn070
Swartz, W., Sumaila, U. R., Watson, R., and Pauly, D. (2010). Sourcing seafood for the three major markets: The EU. USA. Mar. Pol. 34, 1366-1373. doi: 10.1016/j.marpol.2010.06.011

Tao, L. S. R., Lui, K. K. Y., Lau, E. T. C., Ho, K. K. Y., Mak, Y. K. Y., Sadovy de Mitcheson, Y., et al. (2018). Trawl ban in a heavily exploited marine environment: Responses in population dynamics of four stomatopod species. Sci. Rep. 8:17876. doi: 10.1038/s41598-01835804-7

Teixeira, S. F., Mariz, D., de Souza, A. C. F. F., and Campos, S. S. (2016). "Effects of urbanization and the sustainability of marine artisanal fishing: a study on tropical fishing communities in Brazil," in Sustainable Urbanization, ed. M. Ergen (London: IntechOpen). doi: 10.5772/ 62785

Uhlmann, S. S., van Helmond, A. T. M., Stefánsdóttir, E. K., Sigurð̋ardóttir, S., Haralabous, J., Bellido, J. M., et al. (2014). Discarded fish in European waters: General patterns and contrasts. ICES J. Mar. Sci. 71, 1235-1245. doi: 10.1093/icesjms/ fst030

United Nations Environment Programme [UNEP] (2009). Certification and Sustainable Fisheries. Division of Technology, Industry and Economics. Nairobi: UNEP.

Wendling, Z. A., Emerson, J. W., de Sherbinin, A., and Esty, D. C. (2020). Environmental Performance Index. New Haven: CT Yale Center Environment.

Willems, T. (2016). An Ecosystem Approach to Fisheries Management: the Atlantic Seabob Shrimp (Xiphopenaeus kroyeri) in Suriname. Belgium: Ghent University.

Worm, B., Hilborn, R., Baum, J. K., Branch, T. A., Collie, J. S., Costello, C., et al. (2009). Rebuilding Global Fisheries. Science 325, 578-585. doi: 10.1126/science. 1173146

Worms (2019). World Register of Marine Species. Available online at: https://www. marinespecies.org (accessed December 07, 2019).

Ye, Y. (1998). Assessing effects of closed seasons in tropical and subtropical penaeid shrimp fisheries using a length-based yeild-per-recruit model ICES J. Mar. Sci. 55, 1112-1124. doi: 10.1006/jmsc.1998.0415

Conflict of Interest: The authors declare that the research was conducted in the absence of any commercial or financial relationships that could be construed as a potential conflict of interest.

Publisher's Note: All claims expressed in this article are solely those of the authors and do not necessarily represent those of their affiliated organizations, or those of the publisher, the editors and the reviewers. Any product that may be evaluated in this article, or claim that may be made by its manufacturer, is not guaranteed or endorsed by the publisher.

Copyright (C) 2022 Araújo, Mello Filho, Peixoto, Bentes, Santos, Dutka-Gianelli and Isaac. This is an open-access article distributed under the terms of the Creative Commons Attribution License (CC BY). The use, distribution or reproduction in other forums is permitted, provided the original author(s) and the copyright owner(s) are credited and that the original publication in this journal is cited, in accordance with accepted academic practice. No use, distribution or reproduction is permitted which does not comply with these terms. 